ks. Stanisław Wypych CM

\title{
Samarytanie w ujęciu historycznym, geograficznym i religijnym
}

Godny uwagi jest fakt, że Samarytanie w liczbie około sześciuset osób (trzysta w osiedlu Kiriat Luza na zboczach góry Garizim blisko Nablus i tyleż samo w Kiriat Markeh koło Tel Awiwu) zachowali tożsamość etniczną, wiarę i praktyki religijne. Obecnie, nie utożsamiając się ani z Żydami, ani z Palestyńczykami, legitymują się izraelskimi i palestyńskimi dowodami osobistymi. Od roku 1996 ich przedstawiciel zasiada w palestyńskim parlamencie. Szczycą się grobem ich praojca Józefa, który znajduje się w Sychem. Mają własny kalendarz liturgiczny, zachowują własne, tradycyjne obrzędy religijne, a Paschę celebrują jako największe święto. W tym artykule prześledzimy ich historię, geografię i religię z punktu widzenia biblisty. Losy Samarytan i ich doświadczenie religijne nie zostały bowiem wystarczająco utrwalone w literaturze biblijnej, a Józef Flawiusz przedstawił ich dzieje tendencyjnie.

\section{Pojęcie „Samarytanie”}

Określenie „Samarytanie” występuje jeden jedyny raz w pismach Starego Testamentu $(2 \mathrm{Krl} 17,29)$ i nie jest ono jednoznaczne. Można je opisywać z punktu widzenia polityki, geografii i religii. W naszym opracowaniu trudno będzie wyraźnie oddzielić od siebie te punkty widzenia.

Można by przypuszczać, że pojęcie „Samarytanie” pochodzi od nazwy miasta Samaria. W rzeczywistości wywodzi się ono od hebrajskiego czasownika šāmar - czuwać, strzec (domyślnie: strzec Prawa); participium activum liczby mnogiej tego czasownika šôm ${ }^{e}$ rîm oznacza: przestrzegający, stróże (domyślnie: Prawa) ${ }^{1}$.

Termin „Samarytanie” określa najpierw mieszkańców miasta Samarii. Po śmierci Salomona (ok. 930 roku przed Chr.) dokonał się podział zjednoczonego państwa na Królestwo Północne Izraela i Królestwo Południowe

${ }^{1}$ F. Zorell, Lexicon hebraicum et aramaicum Veteris Testamenti, Roma 1968, s. 864n, podaje następujące znaczenia tego czasownika: vigilavit, custodivit, attente observavit, servavit. 
Judy. Podział ten miał bardzo poważne konsekwencje polityczne (odłączenie się dziesięciu pokoleń północnych od Judy i dynastii Dawida) oraz religijne (ustanowienie przez Jeroboama dwóch miejsc kultu: w Dan i Betel, umieszczenie w nich złotych cielców oraz ustanowienie nielegalnego kapłaństwa). Po odłączeniu się od Jerozolimy konieczne było ustanowienie stolicy nowego państwa. Najpierw, przez krótki okres, były nią kolejno: Tirsa, Penuel i Sychem. Dopiero Omri (884-873) ustanowił Samarię stolicą Królestwa Izraela (hebr. Šāmrôn). Jej nazwa wywodzi się od Szemera (por. 1 Krl 16, 24), od którego (w roku 880) za wysoką cenę ten władca zakupił górę Szomron. Położenie nowej stolicy było bardzo dogodne. Znajdowała się ona na ważnym szlaku handlowym i strategicznym. Mieszkańcy Samarii prowadzili wymianę handlową i mieli dobre relacje z Fenicją, której wpływy są widoczne zwłaszcza w dziedzinie architektury i sztuki. Samaria przeżywała okres rozwoju gospodarczego głównie w czasie panowania Omriego i Achaba, a potem za rządów Jeroboama II (782-753). Nie szło to jednak w parze z rozwojem religijnym. W okresie rządów tego ostatniego w Królestwie Północy działali prorocy Amos i Ozeasz, którzy piętnowali niesprawiedliwość społeczną.

Odłączenie się dziesięciu pokoleń od świątyni jerozolimskiej sprawiło, że tworzył się synkretyzm religijny. Syn Omriego Achab (873-853) zbudował w Samarii świątynię Baala (por. 1 Krl 16, 32), najprawdopodobniej pod wpływem swej żony Izebel pochodzącej z Fenicji. Wszystkich władców Królestwa Izraela deuteronomista ocenia negatywnie, gdyż nie zatroszczyli się o czystość religii i kultu. W konsekwencji doprowadziło to do upadku królestwa.

Pojęcia „Samarytanie” nie można ograniczać jedynie do mieszkańców stolicy, ale trzeba je rozciągnąć na ludność regionu. W sensie etnicznym potomkowie Efraima i Manassesa zamieszkiwali także okolice Samarii, czyli region zwany Samarią, położony na północ od Judei i na południe od Galilei². Po zdobyciu Samarii przez Asyryjczyków zapewne wielu mieszkańców spośród tych pokoleń pozostało w okolicy i regionie, i oni, być może, przechowywali tradycje religijne. Okrucieństwo Asyryjczyków nie było aż tak wielkie, jak się niekiedy mniema. Mamy wiele danych przemawiających za tym, że nie wyniszczyli oni całkowicie ludności tubylczej. W okresie reformy w Judzie wielu spośród pokolenia Efraima i Manassesa pozytywnie odpowiedziało na zaproszenie Ezechiasza (728-699) do udziału w obchodach święta Paschy (por. 2 Krn 35, 17-19). Jozjasz (640-609) przeprowadził reformę także w Samarii (por. 2 Krn 34, 6-7.33). Pieniądze na odbudowę świątyni w tym czasie pochodziły także z sakiewek pokoleń Manassesa i Efraima (por. Krn 34, 9).

${ }^{2}$ Por. J. P. MeIer, The Historical Jesus and the Historical Samaritans: What can be Said?, Bb 81 (2000), s. 202-205. 
Samarytanie, także współcześni, opierają przekonania religijne na następujących zasadach: są monoteistami i unikają wyrażeń antropomorficznych, uważają Mojżesza za głównego proroka, kierują modlitwy do Boga przez wstawiennictwo patriarchów i Mojżesza, a górę Garizim uważają za miejsce święte ${ }^{3}$. Jako tekst święty przyjęli tylko Pięcioksiąg Mojżesza w wersji nieco odmiennej od tekstu masoreckiego. Jest to transliteracja tekstu hebrajskiego w odrębnym alfabecie pochodnym od starohebrajskiego. Pięcioksiąg ten jest świadkiem rozpowszechnionej w Palestynie recenzji „protosamarytańskiej”. W porównaniu z tekstem masoreckim wykazuje on około sześciu tysięcy różnic, z tym że ogromna ich większość dotyczy odmienności ortograficznej i fonetycznej . Pięcioksiąg samarytański nie jest sekciarski, ale prezentuje starszą od masoreckiej wersję tekstu. Najstarsze zwoje tego Pięcioksięgu pochodzą z okresu od X do XI wieku.

\section{Zdobycie miasta Samarii i jego konsekwencje}

Wspomnieliśmy o bolesnych konsekwencjach, jakie sprowadził podział na dwa królestwa. W okresie podziału relacje między dwoma królestwami były bardzo trudne (wchodzenie w układy z różnymi mocarstwami i częste walki, powstanie schizmy religijnej oraz ustanowienie nielegalnego kapłaństwa). Ale zagadnienie Samarytan jako złożonej grupy etnicznej pojawia się w momencie zdobycia Samarii przez Asyrię. Nie posiadamy wystarczających informacji o tym wydarzeniu. Relacje biblijne (zob. $2 \mathrm{Krl} 17$ ) są lakoniczne i niejasne. Świadectwo Józefa Flawiusza zaś jest stronnicze i nieprzychylne dla Samarytan. Natomiast przekazy asyryjskie mają inny rodzaj literacki, inny cel i nie jest łatwo uzgodnić ich zawartości z danymi biblijnymi. Nie dziwi więc fakt, że istnieją poważne różnice zdań egzegetów, gdy chodzi o szczegółowe odtworzenie scenariusza zdobycia Samarii.

Rozdział siedemnasty 2 Księgi Królewskiej należy do trudnych tekstów dzieła deuteronomisty ${ }^{5}$. Ma złożoną konstrukcję i egzegeci wyróżniają w nim kilka warstw redakcyjnych. Analizują zatem źródła, warstwy redakcyjne, powtórzenia i glosy. Tekst jest trudny do interpretacji, gdyż został spisany przez deuteronomistów, którzy zburzenie Samarii oceniali z punktu widzenia Judejczyków. Na początku $(17,1-6)$ znajduje się utrzymana w stylu

${ }^{3}$ Zob. B. Ponıży, Samarytanie, [w:] Korzenie przesłania biblijnego Nowego Testamentu, Gniezno 1997, s. 142.

${ }^{4}$ Zob. dobre omówienie tego tematu: A. Tronina, Najstarsze thumaczenia Pięcioksięgu, CTh 69 (1999), s. 47-62.

${ }^{5}$ Omówienie jego redakcji i przesłania zob. M. Z. BrettLer, Ideology, History and Theology in 2 Kings XVII 7-23, VT 39 (1989), s. 268-282; J. ŁACH, Z problematyki literackiej 1-2 Krl, CTh 72 (2002), s. 45-56; S. WyPYch, Przymierze i jego odnowa, Kraków 2003, s. 342-348. 
deuteronomistycznym narracja wydarzeń historycznych, które doprowadziły do upadku Królestwa Północnego, a następne wiersze (17, 7-23) zawierają dokładne omówienie przyczyn tego upadku. Nas interesują głównie wiersze 2 Krl 17, 3-6 i 2 Krl 18, 9-116. Wynika z nich, że król Asyrii Salmanassar V (727-722) wyruszył przeciwko Ozeaszowi (731-722), królowi Izraela, który najpierw się poddał i płacił daninę, potem jednak wszedł w układy z królem Egiptu So. Wówczas król asyryjski zamknął go w więzieniu i oblegał Samarię przez trzy lata. Nie jest jednak jasne, czy chodzi tu o jedną, czy o dwie wyprawy. Nie wiemy również, kiedy nastąpiło uwięzienie Ozeasza. Nie jest wreszcie jasne, kto przesiedlił Izraelitów. Według kroniki babilońskiej (spisanej ok. 500 roku przed Chr.) król Salmanassar zdobył Samarię, ale nie wiadomo, w którym roku jego pięcioletniego panowania. Natomiast inskrypcje asyryjskie przypisują zburzenie Samarii Sargonowi II (722-705). Ze świadectwa sławnej Pryzmy z Nimrud wynika, że podbój Samarii był zapoczątkowany rewoltą „Samarian” i ich knowaniami z nieprzyjaznym królem. Na inskrypcji z Khorsabad widnieje Sargon jako zdobywca Samarii i „kraju Omriego" . Na podstawie tych danych egzegeci starają się odtworzyć przebieg wydarzeń w tym ważnym okresie historii Samarii.

N. Na'aman ${ }^{8}$, biorąc pod uwagę dane biblijne i pozabiblijne, przeprowadził następującą rekonstrukcję wydarzeń, które nas interesują. Ozeasz przy końcu panowania Salmanassara zbuntował się i zawarł przymierze z królem Egiptu So. W konsekwencji przybyli Asyryjczycy i uwięzili Ozeasza. Salmanassar wkrótce zmarł. Nie jest jednak jasne, czy po jego śmierci kontynuowano oblężenie Samarii. Sargon II po wstąpieniu na tron musiał najpierw stłumić bunt w Asyrii. W tym czasie umocniła się koalicja antyasyryjska. Kiedy Sargon II uporządkował sytuację w państwie, wyruszył przeciwko wrogiej mu koalicji, podbił Samarię i inne ośrodki buntu, przyłączył je do terytorium Asyrii, deportował mieszkańców i sprowadził na ich miejsce inne narody. Zdobycie Samarii i deportacja Izraelitów miały - według Na'amana - miejsce w roku 722.

Rozbudowaną hipotezę wydarzeń przedstawili J. H. Hayes i J. K. Kuan9. Ich zdaniem Ozeasz (wspierany przez Achaza) objął kontrolę nad Samarią (730), posłał haracz królowi Asyrii Tiglat Pileserowi III (745-727); podobną

${ }^{6}$ Opinie egzegetów dotyczące źródeł i redakcji interesujących nas wierszy zob. K. L. YounGER, The Fall of Samaria in Light of Recent Research, CBQ 61 (1999), s. 477.

${ }^{7}$ Zob. T. Brzegowy, Księgi historyczne Starego Testamentu, Tarnów 2002³ s. 229-235.

${ }^{8}$ N. NA'Aman, The Historical Background to the Conquest of Samaria (720 Bc), Bb 71 (1990), s. 206-225.

${ }^{9}$ J. H. HAYes, J. K. KuAn, The Final Years of Samaria (730-720), Bb 72 (1991), s. 153-181, zwłaszcza s. 179-181. 
daninę płacił później przez dwa lata (730-728). W roku 728 król Izraela dołączył do koalicji Damaszek-Tyr przeciw Asyrii. Wódz Asyrii wyruszył przeciwko nim i Ozeasz zgodził się płacić daninę (por. 2 Krl 17, 3). Pokój jednak trwał krótko, bo już w roku 725 Ozeasz ponownie się zbuntował (por. 2 Krl 17, 4a). Wówczas Salmanassar zaatakował, zniszczył część Samarii, splądrował świątynię i uwięził Ozeasza. W odpowiedzi podniosła bunt Samaria i Efraim. W trzecim roku panowania Salmanassar znowu wyruszył na wschód (724) i w siódmym roku Ozeasza nastąiłiła deportacja. Tak po raz trzeci Asyryjczycy zdobyli Samarię. Salamanassar zmarł w Tebach w roku 722. Po jego śmierci trwała w Asyrii wewnętrzna walka. Następnie wojska Sargona II wyruszyły przeciwko Tyrowi i Samarii - ślady tego podboju widoczne są w: Hamat, Gaza, Arpad, Simirra, Damaszek. W drugim roku panowania (720-719) Sargon II stłumił bunty i po raz czwarty podbił Samarię. Wówczas deportował Samarytan, ustanowił zarządcę, a miasto zaludnił napływowymi narodami.

Według G. Galila ${ }^{10}$ król Ozeasz był wiernym wasalem podczas panowania Tiglat Pilesera III i później, aż do roku 723. Wtedy nie zapłacił należnej daniny i wszedł w układy z Egiptem przeciw Asyrii. W konsekwencji Salmanassar wyruszył przeciwko Królestwu Izraela i zdobył jego miasta. Ozeasz prawdopodobnie wyszedł mu naprzeciw, by uchronić Samarię przed zniszczeniem, ale został schwytany i uwięziony. Mieszkańcy Samarii jednak się nie poddali i stawiali opór przez dwa i pół roku. W grudniu 722 roku Salmanassar zmarł. Asyryjczycy dalej oblegali Samarię przez pierwszy rok panowania Sargona II. Po pokonaniu ligi nieprzyjacielskiej król asyryjski zdobył Samarię i deportował ludność do górnej Mezopotamii i Medii (27 290). Samaria stała się prowincją Asyrii i została zaludniona przez imigrantów z Babilonii, potem przez szczepy arabskie podbite przez Sargona. Ze zmieszania się tych ludów powstała nowa ludność Samarii - Samarytanie.

K. L. Younger ${ }^{11}$ po przypomnieniu opinii badaczy na temat zburzenia Samarii, po analizie danych kroniki babilońskiej, inskrypcji, reliefu pałacu Sargona II, danych archeologicznych, biblijnych i po ich ocenie uważa, że wydarzenia w interesującym nas okresie miały przebieg następujący: za panowania Tiglat Pilesera III Królestwo Izraela dobrowolnie przyjęło status wasala. Później Ozeasz wszedł w koalicję z królem egipskim So, co spowodowało oblężenie Samarii przez Salmanassara. Samaria została zdobyta w roku 722. Krótko po tym zwycięstwie zmarł Salmanassar. Nadarzyła się okazja, by organizować koalicje antyasyryjskie. Po objęciu władzy Sargon

${ }^{10}$ G. GALIL, The Last Years of the Kingdom of Israel and the Fall of Samaria, CBQ 57 (1995), s. 52-65

${ }^{11}$ K. L. Younger, The Fall of Samaria in Light of Recent Research, CBQ 61 (1999), s. $461-482$. 
II, zajęty rozgrywkami wewnętrznymi, nie mógł od razu przeciwstawić się wrogim mu koalicjom. Dopiero w roku 720 pod Qarquar pokonał zachodnią koalicję, tj. Arpad, Simirra, Damaszek, Hatarika, i przystąpił do oblężenia Samarii. Po krótkim oblężeniu zdobył ją i deportował znaczną liczbę Izraelitów do różnych miejscowości swego imperium.

Po uwzględnieniu opinii egzegetów dotyczących zdobycia miasta Samarii można - też hipotetycznie - odtworzyć interesujące nas wydarzenia. Za panowania Tiglat Pilesera III imperium asyryjskie osiągnęło szczyt swej potęgi. Wspomniany król przeprowadził reformę administracyjną, wcielił do Asyrii podbite tereny i podporządkował je władzy centralnej. Król Izraela Menachem (745-736) przekazywał mu daninę. Natomiast Pekach (735-732) i Resin, król Damaszku, doprowadzili do tzw. wojny syro-efraimskiej, do której chcieli wciągnąć - choć bezskutecznie - króla Judy Achaza (742-727). Asyryjczycy wyruszyli przeciwko zbuntowanym narodom, zdobyli Damaszek, w roku 732 zajęli Gilead i północną część królestwa oraz uprowadzili do Asyrii 13520 osób. Uprowadzeni stanowili pierwszą falę deportowanych, najprawdopodobniej trzon asyryjskiej diaspory. Stolicami poszczególnych prowincji Tiglat Pileser III ustanowił miasta: Dor, Megiddo i Gilead. Najważniejsze znaczenie miało Megiddo.

Z inskrypcji asyryjskich wynika, że następna fala deportowanych, której sprawcą był Sargon II, liczyła 27280 najbogatszych ludzi ${ }^{12}$. Znaczy to, że z Królestwa Północnego do Asyrii zostało przesiedlonych około 40 tys. Izraelitów. Historycy obliczają, że Królestwo to - o powierzchni 7,3 tys. km kw. - w VIII wieku liczyło około 225 tys. ludności. Asyryjczycy deportowali więc jedną piątą mieszkańców kraju. Około 20 tys. Izraelitów schroniło się w Judei. Trzeba zatem przyjąć, że tereny Królestwa Izraela opuściło łącznie około 60 tys. ludzi. Nie wiemy zaś, ile osób poległo w walce z Asyryjczykami. Jednak nic nie wskazuje na to, żeby tereny dawnego Królestwa Północnego nie były zasiedlone przez ludność tubylczą. Można przypuszczać, że na tych obszarach pozostało około 100 tys. mieszkańców, miej więcej tyle, ile znajdowało się w Królestwie Judy przed rokiem 722. Zamieszkiwali oni również okolice Samarii. Nie możemy więc rozumieć dosłownie zapisu autora biblijnego: „Wtedy Pan zapłonął gwałtownym gniewem przeciw Izraelowi i odrzucił go od swego oblicza. Nic nie zostało, jak tylko samo pokolenie Judy" (2 Krl 17, 18).

Nie jesteśmy w stanie określić dokładnie, ilu obcokrajowców przybyło na tereny Królestwa Izraelskiego z Mezopotamii, głównie z Kuty, położonej na północny wschód od Babilonu, z Syrii i z Medii. Pewne jest jednak, że pod względem etnicznym ludność zamieszkująca tereny dawnego Królestwa

${ }^{12}$ Por. ANET, 284n. 
Izraela została bardzo wymieszana, integrując lub nie ze sobą ludność izraelską, osiedleńców z Syrii i Mezopotamii, potem z krajów arabskich podbitych przez Babilończyków, w późniejszym okresie zapewne także przybyszów z innych stron, zwłaszcza z Grecji1 ${ }^{13}$. Wydaje się, że najwięcej imigrantów przybyło z Kuty, gdyż Józef Flawiusz oraz dokumenty rabinistyczne nazywają mieszkańców Samarii „Kutejczykami”. Można jednak przypuszczać, że napływowej ludności nie było więcej niż autochtonów. Wydaje się, że to właśnie oni mieli znaczny wpływ na dalsze dzieje tego regionu.

Zmieniła się jednak sytuacja polityczna; zróżnicowaniu uległa także sytuacja religijna. Ludność napływowa, zmieszana $\mathrm{z}$ autochtonami budowała sanktuaria swoich bożków i szerzyła ich kult. W ten sposób dawne Królestwo Izraela stało się prowincją asyryjską i nie było w niej króla, w którego żyłach płynęłaby krew potomków Jakuba, nie było też własnych kapłanów. Utworzył się tzw. „lud samarytański”.

Odnośnie do bóstw, którym Samarytanie oddawali kult (por. $2 \mathrm{Krl}$ 17, 30-31), są pewne analogie w historii religii. Sukkot-Benota można kojarzyć z bóstwem Sarpanitu, małżonką babilońskkiego boga Marduka. Nergal czczono w Kuta jako pana podziemia. Aszima był prawdopodobnie bóstwem płodności. Adrameleka można utożsamiać z bogiem Adadmiliki, a Anammelek przywołuje skojarzenia z Anu, sumeryjsko-akkadyjskim bóstwem nieba. W Sefarwaim ostatnim dwóm bóstwom składano w ofierze dzieci $^{14}$. Powstał jednak kult synkretyczny, gdyż Samarytanie czcili także Boga Jahwe: „Czcili również Pana, lecz spomiędzy swoich ustanowili sobie kapłanów na wyżynach, którzy sprawowali dla nich obrzędy w świątyniach wyżynnych. Czcili Pana i zarazem służyli bożkom swoim według zwyczajów ludów, z których (krain) zostali przesiedleni” (2 Krl 17,32-33).

\section{Sytuacja religijna na wygnaniu}

Wspomnieliśmy, że Asyryjczycy deportowali około 40 tys. Izraelitów. Trzeba też zaznaczyć, że do Asyrii byli deportowani nie tylko Izraelici. W drugiej połowie VIII wieku przed Chr. Asyryjczycy dokonali ponad 150 deportacji. Ocenia się, że ogólna liczba deportowanych przez nich wahała się między 140 a 600 tys. osób. Trzeba pamiętać przede wszystkim o trzech deportacjach przeprowadzonych przez Babilończyków z terenu Judei i z Jerozolimy. Wprawdzie

${ }^{13}$ Szerzej na ten temat zob. J. WARZECHA, Samarytanie - perspektywa polityczna i religijna, [w:] ,Słowo Twoje jest prawda” (J 17, 17). Księga pamiątkowa dla Księdza Profesora Stanistawa Mędali CM w 65. rocznice urodzin, red. W. Chrostowski, Warszawa 2000, s. 332-335; W. Chrostowski, „Nic nie zostało, jak tylko samo pokolenie Judy” (2 Krl 17, 18b) - czy naprawdę, [w:] Asyryjska diaspora Izraelitów i inne studia, Warszawa 2003, s. 37-44.

${ }^{14}$ Zob. J. WARZecha, Samarytanie..., art. cyt., s. 336. 
dane biblijne się różnią, można jednak wnioskować, że na przełomie lat 598 i 597 (por. Jr 52, 28-30) z Judei uprowadzono 4,6 tys. osób, po zburzeniu Jerozolimy (587/586) 832 osoby, a po zabójstwie Godoliasza (582) 745 osób; łącznie do Babilonii deportowano około 6 tys. Judejczyków ${ }^{15}$.

Rodzi się pytanie, kto przechował rozbudowane tradycje Królestwa Północnego dotyczące życia i działalności proroków czynu Eliasza i Elizeusza (por. $1 \mathrm{Krl}$ 17,1 - $2 \mathrm{Krl}$ 13,21), proroków pisarzy Amosa i Ozeasza, a w pewnym sensie także Nahuma i Habakuka. Istnieją trzy możliwości: (1) przechowali je uciekinierzy z Samarii, którzy osiedlili się w Jerozolimie; (2) tradycje te były żywe wśród ludności, która pozostała na terytorium Izraela; (3) zachowały się one wśród deportowanych w Mezopotamii.

Trudno odpowiedzieć na pytanie, jaką rolę odegrali ci, którzy przemieścili się z Północy na Południe. Nie wiemy, czy przenieśli oni spisany dokument E, lub jaką́s formę karty przymierza, która potem (w okresie Ezechiasza i Jozjasza) stała się podstawą refleksji deuteronomistów. Kiedy więc i jak przekazano tradycję o wspomnianych prorokach? Jeżeli przyjmiemy, że tradycje o prorokach Królestwa Północnego zostały przechowane wśród mieszkańców pozostałych na terytorium byłego królestwa, nasuwa się pytanie, kiedy i w jaki sposób trafiły one do Judy i Jerozolimy, bądź też do uprowadzonych do Babilonii, gdzie dokonano głównej redakcji dzieła deuteronomistycznego?

Zwracamy uwagę na trzecią możliwość, czyli na to, że tradycje te przechowywali deportowani do Mezopotamii. Mało się o tym mówi. Tymczasem wiele wskazuje na to, że właśnie diaspora asyryjska stała się ważnym, a może nawet najważniejszym gwarantem ciągłości tradycji pielęgnowanej na Północy przedwygnaniowego Izraela. Najbardziej prawdopodobne domniemanie jest takie, że wiadomości te przechowano w diasporze asyryjskiej, a następnie zostały one przejęte, aktualizowane i reinterpretowane w środowisku nowej fali uprowadzonych z Jerozolimy i Judy. Jeżeli tak, to należy się liczyć z istnieniem i wielkim wkładem asyryjskiej diaspory w przechowanie tradycji Królestwa Północnego.

W późniejszym okresie diaspora asyryjska została wchłonięta przez wygnańców z Jerozolimy i Judy. Nowa fala uprowadzonych przyswoiła sobie najpierw zastane osiągnięcia, a potem przedstawiła je w duchu całkowitej separacji i izolacji od dawnych pobratymców z Północy. W kręgach deuteronomistów zauważa się wyraźną niechęć do Królestwa Północnego i jego mieszkańców, a także przemilczenia dotyczące diaspory asyryjskiej. Deuteronomiści zastosowali więc zamiast polemiki taktykę przemilczenia.

${ }^{15}$ Zob. W. Chrostowski, Asyryjska diaspora Izraelitów - wyzwania i perspektywy badawcze, [w:] Asyryjska diaspora Izraelitów i inne studia, Warszawa 2003, s. 22-27. 
W ten sposób wygnańcy judzcy w Babilonii stali się jedynymi i wyłącznymi spadkobiercami przedwygnaniowego Izraela. Im przypisuje się redakcję dzieła deuteronomistycznego, dokumentu kapłańskiego P i - być może - także Kodeksu Świętości (Kpł 17-26).

Napięcia między deportowanymi z Północy i Południa widoczne po powrocie $\mathrm{z}$ wygnania najprawdopodobniej istniały już wcześniej w kraju uprowadzenia. Faktem jest, że Ezechiel kierował swoje przesłanie do jednej i do drugiej grupy, wzywając bezskutecznie do zjednoczenia. Można przypuszczać, że także potomkowie uprowadzonych z Królestwa Północnego wracali z niewoli w przekonaniu, że będą mieli coś do powiedzenia w rozpoczynającym się procesie odnowy życia religijnego i społecznego. Zostali jednak odepchnięci. Zamiast zgody wybrano podczas odbudowy ekskluzywizm i separację, które przesądziły o tym, że w nowej, żydowskiej świadomości nie znaleziono miejsca dla pobratymców z Północy i ich potomków. Później rabini zupełnie wymażą ze świadomości narodowej pamięć o diasporze asyryjskiej ${ }^{16}$.

\section{Okres odbudowy społecznej i religijnej}

Edykt Cyrusa (538) otworzył możliwości powrotu uprowadzonych do Judei. W wielkim imperium perskim prowincjami zarządzali namiestnicy (pechah). Historycy dyskutują, czy Judea od początku była niezależną prowincją, czy też najpierw podlegała Samarii. Bibliści przyjmujący pierwszą możliwość podają imiona namiestników okresu powygnaniowego: Szeszbassar, Zorobabel, Chananiasz, Nehemiasz (445-433) ${ }^{17}$. Namiestnik perski wraz z urzędnikami w liczbie około 150 stanowili zarząd prowincji. Istniał również żydowski samorząd składający się z rady starszych (głowy domów, starszyzna, wiodące postacie związków plemiennych) i kolegium kapłanów (kapłani i lewici) ${ }^{18}$.

Dokładne określenie terytorium Judy w okresie drugiej świątyni jest trudnym zagadnieniem. Biorąc pod uwagę pieczęcie, można przypuszczać, że rozciągało się ono na terenie $30 \mathrm{~km}$ wokół Jerozolimy i wynosiło około 1,7 tys. km kw. powierzchni, którą zasiedlało około 17,3 tys. ludności ${ }^{19}$. Część spośród nich uprawiała rolę, inni zajmowali się hodowlą lub handlem

${ }^{16}$ Hipotezę taką przedstawił W. Chrostowski, Asyryjska diaspora Izraelitów..., art. cyt., s. 28-34, i za nią się opowiadamy.

${ }^{17}$ Zob. J. WArzecha, Początek odbudowy po wygnaniu babilońskim, [w:] Pan moim świattem. Księga pamiątkowa dla Księdza Profesora Jerzego Chmiela w 65. rocznicę urodzin, Warszawa 2000, s. 341.

${ }^{18}$ Zob. tamże, s. 341n.

${ }^{19}$ Zob. tamże, s. 343. 
albo opiekowali się świątynią. Wspólnota składała się głównie z dwóch grup: ubogich autochtonów, którzy pozostali w kraju, i bardziej zamożnych repatriantów. W takiej wspólnocie nie mogło obyć się bez konfliktów.

Był to bardzo ważny okres historii zbawienia ${ }^{20}$. W tym czasie kształtował się żydowski kanon Pisma Świętego, odnowiono kult i odbudowano świątynię; budziły się i szerzyły oczekiwania eschatologiczne. Istniały głównie trzy nurty teologiczne: deuteronomistyczny, kapłański związany ze świątynią i kultem oraz profetyczny o charakterze zbawczym.

Najpilniejszym zadaniem w tym okresie była odbudowa świątyni i odnowa życia religijnego ${ }^{21}$. Po przezwyciężeniu początkowych trudności, dzięki nawoływaniu proroków Aggeusza i Zachariasza oraz przychylnej postawie Dariusza, króla perskiego, świątynia została odbudowana i poświęcona w roku 515. Wprawdzie nie była ona tak okazała, jak pierwsza, wzbudziła jednak wielką radość Judejczyków. Dokonało się to w klimacie wielu nieporozumień z Samarytanami. W Księdze Ezdrasza czytamy, że gdy „wrogowie Judy i Beniamina" dowiedzieli się, iż repatrianci odbudowują świątynię, „przystąpili do Zorobabela, do Jozuego oraz przedstawicieli rodów i rzekli do nich: «Chcemy budować $\mathrm{z}$ wami, albowiem czcimy Boga naszego jak wy i Jemu składamy ofiary od czasów Asarhaddona, króla Asyryjskiego, który nas tu sprowadził». Lecz Zorobabel, Jozue i pozostali naczelnicy rodów izraelskich im odpowiedzieli: «Nie wolno wam razem z nami budować domu dla Boga naszego, ale my sami budować będziemy dla Pana, Boga izraelskiego, jak nam rozkazał Cyrus, król perski»” (Ezd 4, 2-3). Z przytoczonego tekstu nie można wnioskować, że wszyscy mieszkańcy Samarii mieli takie przeświadczenie. Ale o ich wrogiej postawie dowiadujemy się także z Ezd 4, 6. 7-22. Tekst ten odnosi się jednak do budowy murów, a nie świątyni. Wrogość Samarytan w tym wypadku miała charakter polityczny, a nie religijny. Nie można zatem twierdzić, że już w czasie Zorobabela dokonał się głęboki podział między Judą a Samarią.

Jak można więc odtworzyć relacje między Żydami i Samarytanami po niewoli? Samarytanie pod przewodnictwem namiestnika Sanballata przeciwstawili się wysiłkom odbudowy Jerozolimy (por. Ne 4; 6). Spory te - jak wspomniano - miały jednak raczej polityczny charakter, a nie religijny. Warto zauważyć, że wśród kobiet, które Żydzi poślubili niezgodnie z Prawem, nie wymienia się Samarytanek (Ne 13, 23). Na podstawie licznych imion mających związek z imieniem Boga Jahwe można wnioskować, że rządząca warstwa Samarytan z czasów perskich oddawała cześć Jahwe.

${ }^{20}$ Zob. tamże, s. 347-350.

${ }^{21}$ Zob. tamże, s. 350-356. 
W V wieku przed Chr. Żydzi przebywający w Egipcie zwracali się do przywódców zarówno w Jerozolimie, jak i w Samarii z prośbą o pomoc w odbudowie swojej świątyni na Elefantynie.

Po podboju Palestyny przez Aleksandra Wielkiego (332 rok przed Chr.) Samarytanie, wykorzystując próżnię polityczną w czasie walk tego wodza z Persami, zbudowali w pobliżu Sychem świątynię dla Jahwe, mającą rywalizować ze świątynią jerozolimską. Według Józefa Flawiusza budowlę tę wznieśli w roku 330, a poświęcili ją w roku 328. Na początku Samarytanie wspierali Aleksandra Wielkiego, ale gdy ten mianował Andromachussa zwierzchnikiem Samarii, okazali niezadowolenie. Wtedy Aleksander zemścił się, zburzył Samarię i wypędził jej mieszkańców, którzy schronili się w Sychem. Później Samarytanie nie brali udziału w walkach prowadzonych przez Machabeuszów, a mimo to Antioch IV Epifanes (175-164) nakazał poświęcić ich świątynię Zeusowi Kseniosowi. W 2 Księdze Machabejskiej czytamy: „ale zbezcześcili zarówno świątynię w Jerozolimie, którą mieli oddać Zeusowi Olimpijskiemu, jak i tę na Garizim, którą [...] mieli oddać Zeusowi Kseniosowi” (6, 2). Świątynię tę zburzył Jan Hirkan w 21 dniu miesiąca Kislew 128 roku i już nigdy nie została odbudowana. Wtedy też nastąpił definitywny podział między Samarią a Judejczykami.

Później Samaria stała się bogatym miastem hellenistycznym. Wprawdzie Jan Hirkan zburzył ją w 128 roku, ale znowu ją odbudowano po zajęciu Palestyny przez Rzymian (63). Herod Wielki z przepychem rozbudował Samarię i nazwał ją Sebastą. Miasto odbudowane z wielkim rozmachem zostało zburzone podczas pierwszej wojny żydowskiej (70), wkrótce znów odbudowane przeżywało okres rozkwitu aż do ostatecznego upadku w czasach bizantyńskich ${ }^{22}$. Góra Garizim pozostaje dotąd świętą górą Samarytan i miejscem ich kultu.

Jakie więc były społeczne i religijne przyczyny rozłamu pomiędzy $\dot{Z} y$ dami a Samarytanami? Zagadnienie to jest przedmiotem żywej dyskusji zarówno w literaturze światowej, jak i w polskiej ${ }^{23}$. Przyczyny te można sformułować następująco ${ }^{24}$ :

${ }^{22}$ Por. Stownik wiedzy biblijnej, red. B. M. Metzger, M. D. Coogan, konsultacja wydania polskiego W. Chrostowski, Warszawa 1997, s. 699.

${ }^{23}$ Np. B. Poniży, Samarytanie, art. cyt., s. 143, przedstawia je w następujący sposób: nieprzyjęcie zaproszenia przez Samarytan do wspólnego celebrowania Paschy w okresie reformy Ezechiasza; zawieranie małżeństw mieszanych po roku 722; odrzucenie przez repatriantów oferty Samarytan przy odbudowie świątyni; stworzenie przez Samarytan odrębnego miejsca kultu na górze Garizim (328); sprofanowanie świątyni jerozolimskiej przez rozrzucenie tam ludzkich kości; jawne ataki na Żydów galilejskich zmierzających do Jerozolimy na święto Paschy.

${ }^{24}$ Przytaczamy je tu za J. Warzecha, Samarytanie..., art. cyt., s. 339-343. 
- gdy Judejczycy odbudowali świątynię (515 rok przed Chr.), kult jerozolimski przyciągał żydowską ludność z Samarii (por. 2 Krl 17, 34b40). Dopóki teren Judy stanowił część prowincji Samarii, nie budziło to zastrzeżeń. Natomiast gdy Judea stała się samodzielną prowincją, sytuacja znacznie się skomplikowała. Judejczycy zorganizowali się na sposób plemienno-etniczny (każdy musiał uzasadnić przynależność do określonego rodu); Samarytanie zaś nie mogli tego zrobić;

- dla Samarytan nie było łatwym przyjęcie przekonania deuteronomistów, że jedynym miejscem kultu wybranym przez Jahwe jest Jerozolima;

- w czasie działalności Nehemiasza w Jerozolimie Samarytanie wraz z namiestnikiem Sanballatem sprzeciwiali się odbudowie murów Jerozolimy (por. Ne 4; 6), a Nehemiasz nie widział możliwości współpracy z nimi (Ne 2-6). Tymczasem w księgach prorockich (np. Iz 56; 60-62; Jon) i dydaktyczno-historycznych (Rut i Jud) znajdujemy inne świadectwo. Jest nawet możliwe, że istniała wówczas partia popierająca powszechne zbratanie. Można wnioskować, że na początku okresu perskiego napięcia między Judą a Samarią nie były zbyt wielkie;

- istotnym wydarzeniem było zbudowanie przez Samarytan świątyni na górze Garizim. Nie doprowadziło to jeszcze do głębokiego podziału. Podział dokonywał się stopniowo i doszedł do punktu kulminacyjnego w okresie Hasmonejczyków (II wiek). Był to zatem proces długotrwały;

- Samarytanie przejęli z kanonu żydowskiego tylko Pięcioksiąg, co wskazuje na ich konserwatyzm religijny odcinający się od wszelkich innowacji, jakie dokonały się w Judzie po okresie niewoli. Nie przyjęli oni innych ksiąg Starego Testamentu ze względu na zawarte w nich oczekiwania mesjańskie. W Judzie łączono je z pomazańcami, królem lub kapłanem, oni natomiast oczekiwali proroka na miarę Mojżesza.

\section{Samarytanie w pismach Nowego Testamentu}

Po narodzeniu Jezusa relacje między Żydami a Samarytanami miały zróżnicowaną dynamikę. Wspomnimy tylko niektóre wydarzenia. Podczas obchodów święta Paschy za prokuratora Konopiusza (lata 6-8) Samarytanie rozrzucili na krużgankach i na dziedzińcu świątyni ludzkie kości, bezczeszcząc tym samym świątynię. Gdy Samarytanie zaatakowali Galilejczyków idących na święto Paschy do Jerozolimy, Żydzi w odwecie spalili kilka ich wiosek. W wojnie żydowskiej Samarytanie wystąpili przeciwko Rzymianom. Po drugim powstaniu żydowskim (135 rok) Hadrian kazał wybudować na górze Garizim świątynię ku czci Jowisza ${ }^{25}$.

${ }^{25}$ Szerzej na ten temat zob. B. Poniży, Samarytanie..., art. cyt., s. 140 n. 
Zapytajmy, jakie zapisy dotyczące relacji Jezusa i Jego uczniów z Samarytanami przekazali święci ewangeliści? W źródle Q, z którego korzystali najprawdopodobniej ewangeliści Mateusz i Łukasz, a także w ewangelii według Marka nie ma wzmianki o Samarytanach. W ewangelii według Mateusza pojawiają się w negatywnym nakazie, by apostołowie nie szli do pogan i Samarytan: „Nie idźcie do pogan i nie wstępujcie do żadnego miasta samarytańskiego! Idźcie raczej do owiec, które poginęły z domu Izraela" (Mt 10, 5b-6). Relacja ta nie została zaczerpnięta - uważają egzegeci - ani ze źródła Q, ani z przekazu Marka, ale pochodzi od Mateusza; możliwy jest również wpływ gminy judeochrześcijańskiej ${ }^{26}$.

Ewangelista Łukasz (wyraźnie) i autor czwartej Ewangelii (niewyraźnie) wspominają o głoszeniu dobrej nowiny Samarytanom. W ewangelii według Łukasza 17, 1-19 mamy relację o uzdrowieniu dziesięciu trędowatych, spośród których tylko Samarytanin przyszedł, by podziękować Jezusowi. Inna wzmianka o Samarytanach w trzeciej ewangelii znajduje się w opowiadaniu o podróży Jezusa wraz z uczniami do Jerozolimy na święto Paschy (Łk 9, 52-53). Samarytanie nie przyjęli Go życzliwie, ponieważ zmierzał do Jerozolimy. Jakub i Jan, jako prawdziwi synowie gromu, chcieli sprowadzić na Samarytan ogień z nieba. Bibliści uważają, że mamy tu do czynienia $\mathrm{z}$ tradycją przedłukaszową ${ }^{27}$.

Dobrze znana jest przypowieść o miłosiernym Samarytaninie (Łk 10, 30-35). Scena ta rozgrywa się w drodze „z Jerozolimy do Jerycha” (w. 30). Jako główne postacie w przypowieści występują z jednej strony kapłan i lewita, a z drugiej Samarytanin. Uczony w piśmie stawia pytanie: Kto jest moim bliźnim? Znał zapewne starotestamentalne przykazanie miłości: „Nie będziesz szukał pomsty, nie będziesz żywił urazy do synów twego ludu, ale będziesz miłował bliźniego jak siebie samego" (Kpł 19, 18). Był przekonany, że bliźni to członek narodu wybranego. Jezus wskazuje na Samarytanina jako na bohatera przypowieści i w ten sposób daje do zrozumienia, że nie można ograniczać miłości bliźniego i praktykować jej tylko w obrębie jednego narodu ${ }^{28}$.

Egzegeci dyskutują, czy tradycja zawarta w tej przypowieści sięga Jezusa historycznego, czy jest owocem teologii pierwotnego Kościoła, czy też pochodzi od autora ewangelii? Wydaje się, że materiał najprawdopodobniej pochodzi z tradycji L, a opracował go Łukasz. Chociaż historia redakcji tekstu jest dyskutowana, przesłanie jest jasne: ranny nie otrzymał

${ }^{26}$ Zob. J. P. MeIER, The Historical Jesus and the Historical Samaritans..., art. cyt., s. 218-220.

${ }^{27}$ Zob. tamże, s. 222-224.

${ }^{28}$ Więcej informacji na temat tej przypowieści zob. M. Rosık, Jezus i Jego misja. W kręgu orędzia Ewangelii synoptycznych, Kielce 2003, s. 132-143 
pomocy od Judejczyków (kapłana, lewity), ale zajął się nim Samarytanin. Stąd wniosek, że współczucie i pomoc bliźniemu powinny być okazywane niezależnie od jego przekonań religijnych ${ }^{29}$.

Według Dziejów Apostolskich prześladowanie chrześcijan w Judei doprowadziło do misji w Samarii: „Wszyscy [...] rozproszyli się po okolicach Judei i Samarii. [...] Ci, którzy się rozproszyli, głosili w drodze słowo. Filip przybył do miasta Samarii i głosił im Chrystusa. Tłumy słuchały z uwaga i skupieniem słów Filipa" (Dz 8, 1-6).

W czwartej Ewangelii również są wzmianki o Samarytanach. Najbardziej znany jest opis spotkania Jezusa z Samarytanką (J 4, 4-42). Jest to fragment bardzo złożony. Język i teologia są typowe dla autora tej ewangelii. Akcja rozgrywa się u stóp góry Garizim, w pobliżu Sychem, gdzie studnia Jakubowa była symbolem darów Boga dla Izraela. Obietnica wody żywej oznacza objawienie Boże, które Jezus przynosi w słowie i postawie życia. Jezus objawia się tu jako źródło wody żywej „wytryskującej ku życiu wiecznemu” (w. 14), a także jako ustawodawca nowej formy kultu „w Duchu i prawdzie” (w. 23n). Samarytanka odkrywa, że nie jest On takim Żydem, jak inni i rozpoznaje w Nim proroka i Mesjasza. Wyznaje, że On - Żyd - jest prawdziwym prorokiem; Jezus zaś podkreśla, że „zbawienie bierze początek od Żydów” (w. 22). Dialog kończy stwierdzenie: „On prawdziwie jest Zbawicielem świata”

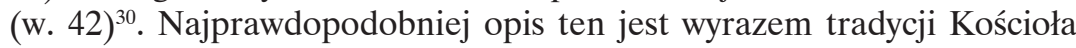
pierwszego wieku i nie sięga warstwy Jezusa historycznego.

W obiegowym rozumieniu często można spotkać określenie „schizma Samarytan”. Schizma zakłada wcześniejszą jedność. Powstaje pytanie, czy istniała wcześniej taka jedność między Żydami i Samarytanami?

Po okresie wygnania do Babilonii pojawił się termin „Żydzi” odnoszący się do mieszkańców terytorium Judy. Tę grupę religijną tworzyli repatrianci, którzy odbudowali kult i świątynię, oraz ci mieszkańcy Judei, którzy nie byli w niewoli. Natomiast Samarytanie pochodzący z pokolenia Efraima i Manassesa nigdy nie byli określani w Palestynie jako Żydzi. Wobec tego lepiej jest mówić o Judejczykach i Samarytanach, którzy wierzyli i czcili Jahwe jako jedynego Boga zgodnie z przesłaniem Pięcioksięgu. Wytworzyły się jednak różne praktyki kultu. W Samarii dokonało się to pod wpływem ludzi z Asyrii, Babilonii, Persji i tych ze świata arabskiego i hellenistycz-

${ }^{29}$ Zob. J. P. Meier, The Historical Jesus and the Historical Samaritans..., art. cyt., s. 224-226.

${ }^{30}$ Omówienie tego fragmentu zob. L. STACHOwIAK, Ewangelia wedtug św. Jana. Wstęp. Przekład z oryginatu. Komentarz, [w:] PŚNT, t. 12, Poznań-Warszawa 1975, s. 173-185; S. MĘDALA, Ewangelia św. Jana. Listy Powszechne. Apokalipsa, [w:] Wprowadzenie w myśl i wezwanie ksiag biblijnych, t. 10, Warszawa 1992, s. 35n. 
nego. Były to zatem dwa nurty - raz opozycyjne względem siebie, kiedy indziej przyjazne, zależnie od uwarunkowań okresu historycznego ${ }^{31}$.

Jezus nie prowadził misji wśród Samarytan, ale nie zauważa się także u Niego śladów niechęci wobec nich. W ewangeliach Łukasza i Jana znajdujemy ślady przekonań pierwotnego Kościoła, które wskazują na otwartą postawę Jezusa wobec Samarytan ${ }^{32}$. Świadczą one także o tym, że dość wcześnie uczniowie Jezusa z powodzeniem głosili Samarytanom Jego orędzie.

\section{Sommario}

\section{Samaritani nel contesto storico, geografico e religioso}

Il termine „Samaritani” deriva dal verbo ebraico šāmar “vigilare”, „custodire”. Gli Assiri, dopo aver conquistato la capitale Samaria (722) deportarono circa 40 mila Israeliti in Mesopotamia i quali conservarono la tradizione dei profeti del Regno del Nord: Elia, Eliseo, Amos ed Osea. Nella regione di Samaria rimasero circa 100 mila Israeliti, ma vi arrivarono molti altri popoli dalla Siria, Assiria, Persia, Media e dal mondo ellenistico. Così si formò una comunità assai composita che adottò un rito speciale.

Dopo il periodo di deportazione (di esilio), quando i rimpatriati Giudei si dedicarono al rinnovamento del culto e alla ricostruzione del tempio di Gerusalemme, i Samaritani espressero il desiderio di parteciparvi. Ma il loro desiderio fu respinto dai rimpatriati. Allora i Samaritani, per ragioni politiche, si opposero alla ricostruzione delle mura di Gerusalemme e costruirono un proprio tempio sul monte Garizim (328) che fu distrutto da Giovanni Ircano (128), procurando una profonda spaccatura tra Giudei e Samaritani.

Spesso si parla di „scisma dei Samaritani”. In realtà si tratta piuttosto di due correnti religiose, basate sul Pentateuco. I Samaritani sono monoteisti, considerano Mosè come un profeta, indirizzano le preghiere a Dio tramite i patriarchi e Mosè, accettano il Pentateuco, considerano il monte Garizim come un luogo santo, hanno il proprio calendario liturgico e riti religiosi.

Gesù non predicò la buona novella ai Samaritani (non si trovano tracce nella fonte $\mathrm{Q}$ $\mathrm{e}$ in Marco). I due evangelisti testimoniano che Gesù non era contro i Samaritani (vedi la parabola del buon Samaritano - Luca 10,30-35 ed il colloquio con la Samaritana - Giov. 4,4-42). I discepoli di Gesù ben presto, con un notevole successo, cominciarono a predicare il messaggio del loro Maestro ai Samaritani (cf. Atti 8,1-6).

${ }^{31}$ Zob. J. P. MeIER, The Historical Jesus and the Historical Samaritans..., art. cyt., s. 215-217.

${ }^{32}$ Omówienie tego zagadnienia zob. tamże, s. 218-232. 


\section{POLECAMY}

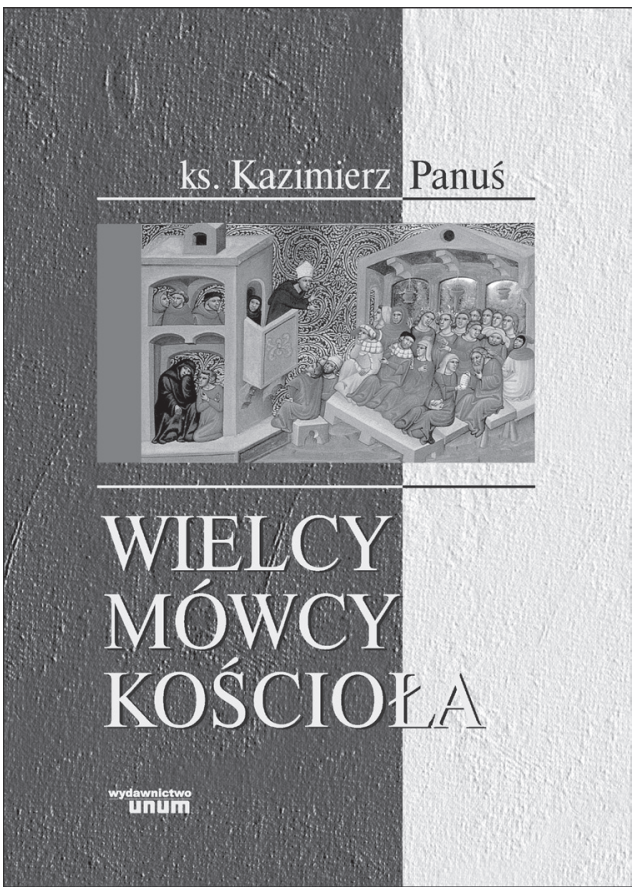

Niniejsza publikacja prezentuje sylwetki 25 wybitnych kaznodziejów Kościoła powszechnego, którzy-zdaniem autora - wnieśli istotny wkład w głoszenie ewangelii Chrystusowej. Mówcy ci to wielkie osobowości, bohaterzy wiary, nierzadko kanonizowani święci: biskupi, zakonnicy, kapłani diecezjalni. Pełniejsze spotkanie z nimi umożliwia załączony do każdej sylwetki, reprezentatywny dla niej, tekst kaznodziejski. Nie ma w tym opracowaniu mistrzów polskiej ambony, gdyż będzie im poświęcony odrębny tom.

Przywołując wielkich mistrzów ambony, od początków chrześcijaństwa do końca XX wieku, autor poświęca szczególną uwagę kaznodziejom czasów nowożytnych i najnowszych. Wieloletni brak zainteresowania kazaniami przez ośrodki badawcze, przez historyków, filologów i badaczy kultury sprawił bowiem, iż nadal - nawet wykształconemu Polakowi - niewiele mówią tak ważni dla kaznodziejstwa niemieckiego kaznodzieje, jak: Jan Tauler, Abraham a Sancta Clara, Paul Wilhelm von Keppler czy Michael von Faulhaber, dla kaznodziejstwa francuskiego: Jacques-Bénigne Bossuet, Henryk Lacordaire, Henryk Pinard de la Boullaye czy Noël Quesson, dla kaznodziejstwa angielskiego: John Henry Newman, dla kaznodziejstwa hiszpańskiego: św. Wincenty Ferrer czy św. Jan z Avili, dla kaznodziejstwa włoskiego: św. Wawrzyniec z Brindisi, Paweł Segneri Starszy czy św. Leonard z Porto Maurizio, dla kaznodziejstwa portugalskiego: Antoni Vieira, dla kaznodziejstwa węgierskiego: Ottokár Prohászka, dla kaznodziejstwa amerykańskiego: Fulton John Sheen. Z tymi i z innymi wielkimi mówcami Kościoła będzie się można spotkać na kartach tej książki. Warto także podkreślić, iż Czytelnik polski ma po raz pierwszy okazję zapoznać się z kazaniami św. Jana z Avili i Abrahama a Sancta Clara. Dotąd bowiem ci charyzmatyczni mówcy skutecznie unikali szkietka i oka polskich badaczy.

\section{8 stron $\cdot$ format $165 \times 235 \mathrm{~mm} \cdot$ oprawa twarda $\cdot$ cena $\mathbf{4 0}$ zt}

\section{Zamówienia}

Wydawnictwo UNUM · ul. Kanonicza 3 · 31-002 Kraków

tel. (12) $4225690 \cdot$ e-mail: unum@ptt.net.pl

Koszt przesyłki ponosi wydawnictwo. 